\title{
Kesulitan Siswa Madrasah Ibtidaiyah pada Materi Pecahan Berdasarkan Langkah Polya
}

\author{
Nenden Yuliani Pratiwi ${ }^{1^{*}}$, Wahyu Hidayat ${ }^{2}$ \\ 1,2Program Studi Pendidikan Matematika, Institut Keguruan dan Ilmu Pendidikan Siliwangi, \\ Cimahi, Indonesia; ${ }^{1 *}$ pratiwi93.ny@gmail.com; ${ }^{2}$ wahyu@ikipsiliwangi.ac.id
}

Info Artikel: Dikirim: 4 Mei 2020; Direvisi: 17 Juni 2020; Diterima: 14 September 2020

Cara sitasi: Pratiwi, N.Y., \& Hidayat, W. (2020). Kesulitan Siswa Madrasah Ibtidaiyah pada Materi Pecahan Berdasarkan Langkah Polya. JNPM (Jurnal Nasional Pendidikan Matematika), $4(2), 248-262$.

Abstrak. Pecahan penting untuk dipelajari dan dikuasai siswa karena merupakan materi esensial dalam matematika dan kehidupan sehari-hari. Namun pada kenyataannya siswa masih mengalami kesulitan dalam mempelajari pecahan. Penelitian ini bertujuan untuk menganalisis kesulitan siswa dalam mempelajari pecahan berdasarkan langkah Polya dan mendeskripsikan faktor-faktor penyebab kesulitan tersebut. Penelitian ini merupakan penelitian kualitatif dengan metode deskriptif. Subjek penelitian sebanyak 20 orang siswa kelas III salah satu MI di Kabupaten Bandung. Teknik pengumpulan data yang digunakan dalam penelitian ini adalah tes tertulis dan wawancara. Analisis data dilakukan dengan tiga langkah yaitu reduksi data, penyajian data dan penarikan kesimpulan. Hasil penelitian menunjukkan kesulitan pada: langkah memahami masalah yaitu siswa tidak dapat mengidentifikasi unsur yang diketahui dan ditanyakan pada soal; langkah merencanakan penyelesaian yaitu siswa tidak bisa membuat model matematika yang berkaitan dengan lambang pecahan; langkah melaksanakan rencana penyelesaian yaitu siswa tidak dapat merinci langkah-langkah penyelesaian yang harus digunakan untuk menyelesaikan soal; dan terakhir langkah memeriksa kembali kebenaran solusi yang diperoleh yaitu siswa tidak bisa memeriksa kembali kebenaran jawaban yang telah diperoleh. Secara keseluruhan pendekatan pembelajaran dan bahan ajar yang digunakan dianggap paling berpengaruh dalam masalah kesulitan siswa mempelajari pecahan ini. Analisis kesulitan ini dapat digunakan oleh guru untuk membuat rencana pembelajaran dengan memperhatikan langkah Polya tersebut.

Kata Kunci: Langkah Polya, Kesulitan Siswa, Pecahan.

\begin{abstract}
Fractions are important for students to learn and master because they are essential in mathematics and everyday life. But in reality, students still have difficulty learning fractions. This study aims to analyze students' difficulties in studying fractions based on Polya's steps and describe the factors that cause these difficulties. This research is qualitative research with descriptive methods. The research subjects were 20 students of class III of one MI in Bandung Regency. Data collection techniques used in this study were written tests and interviews. Data analysis was
\end{abstract}


carried out in three steps: data reduction, data presentation, and conclusion drawing. The results showed that, first, difficulties in understanding the problem, namely, students could not identify the elements that were known and asked the questions. Second, the step of planning completion, namely, students cannot make mathematical models related to fraction symbols. Third, efforts to carry out the completion plan, namely, students cannot detail the steps for completing the solution that must be used to solve the problem. The last step is to check the correctness of the solution obtained, namely that students cannot review the correctness of their answers. Overall, the learning approach and teaching materials used are considered the most influential in students' difficulty in learning these fractions. This difficulty analysis can be used by teachers to make lesson plans by paying attention to Polya's steps.

Keywords: Polya's steps, Students' difficulties, Fraction.

\section{Pendahuluan}

Pecahan di tingkat sekolah dasar dipelajari mulai dari kelas II sampai dengan kelas VI yang termasuk ke dalam kompetensi bilangan dimulai dari pecahan dasar sampai kompleks serta di tingkat SMP pecahan dipelajari kembali di kelas VII dengan muatan materi yang lebih kompleks (Indriani, 2016; Liestarie \& Karlimah, 2017; Peraturan Menteri Pendidikan dan Kebudayaan Republik Indonesia, 2018; Saleh, Prahmana, Isa \& Murni, 2018; Saputri \& Mampouw, 2018). Pecahan banyak digunakan sebagai dasar memperoleh solusi pada materi matematika lainnya seperti menghitung persentase, perbandingan senilai dan berbalik nilai, menghitung peluang suatu kejadian dan banyak lagi. Dengan demikian, pecahan sebagai prasyarat untuk beberapa materi dalam matematika seperti bilangan rasional, aritmteika sosial, perbandingan, desimal, persentase dan peluang.

Pecahan penting untuk dipelajari dan dikuasai siswa karena merupakan materi prasyarat dalam mempelajari materi matematika berikutnya dan pecahan juga berhubungan erat dengan kehidupan sehari-hari (Prayitno \& Wulandari, 2015; Zabeta, Hartono \& Putri, 2015). Selain itu, pecahan juga memberikan kontribusi pada disiplin ilmu lainnya seperti, fisika, ekonomi, kimia, biologi bahkan ilmu agama. Namun, pada kenyataannya pecahan menjadi salah satu materi yang dianggap sulit oleh siswa kelas III meskipun dasar-dasar pecahan sudah dipelajari di kelas II.

Berdasarkan pengalaman peneliti pada saat mengajar pecahan kesulitan siswa lebih banyak mengenai cara menyelesaikan masalah atau soal cerita yang berkaitan dengan konsep pecahan. Kebanyakan siswa belum dapat membuat model matematika ke dalam lambang pecahan karena masih bingung untuk menentukan pembilang dan penyebutnya. Selain itu, siswa juga masih kurang paham mengenai nilai penyebut yang diperoleh dari keseluruhan bagian yang ada, masih ada siswa yang memodelkan nilai penyebut dari sisa bagian yang sudah diambil pembilang. Hal ini 
relevan dengan hasil penelitian Deringöl (2019) yang menyebutkan bahwa siswa di tingkat sekolah dasar mengalami kesulitan dalam merepresentasikan pecahan ke dalam model matematika, membedakan pembilang dan penyebut serta menyelesaikan masalah sehari-hari. Pecahan merupakan salah satu konsep matematika yang sulit dipahami dan memungkinkan untuk terjadi miskonsepsi dan verbalisme (Kania, 2018). Hal ini sejalan dengan hasil penelitian Nasiruudin \& Hayati (2019) menyebutkan bahwa siswa kesulitan dalam melakukan perhitungan pengurangan, perkalian dan pembagian pecahan, siswa kesulitan dalam memahami konsep operasi hitung pecahan serta kesulitan dalam membedakan pembilang dan penyebut.

Penelitian mengenai kesulitan dalam mempelajari pecahan dianggap suatu hal yang penting untuk dilakukan dalam mengkaji dan merinci bagian-bagian yang sulit dalam pecahan dan untuk mengetahui faktor penyebabnya. Penelitian terkait kesulitan siswa dalam mempelajari pecahan sebenarnya sudah banyak dilakukan oleh peneliti sebelumnya, seperti penelitian mengenai kesulitan menyelesaikan soal operasi hitung pecahan, analisis hambatan belajar pada pecahan dan kesulitan siswa dalam menyelesaikan soal cerita matematika topik pecahan ditinjau dari Gender (Aminah \& Kurniawati, 2018; Nasiruudin \& Hayati, 2019; Rohmah, 2019; Suarjana, Parmiti \& Safitri, 2018). Namun untuk penelitian mengenai kesulitan dalam mempelajari pecahan yang melakukan pengkategorian berdasarkan langkah Polya dengan menggunakan subjek siswa MI merupakan suatu hal yang baru untuk dilakukan.

Langkah Polya menurut Polya (2004) terdiri dari empat langkah yaitu memahami masalah (understanding the problem), menyusun rencana (devising a plan), melaksanakan rencana penyelesaian (carrying out the plan) dan memeriksa kembali kebenaran solusi (looking back). Berdasarkan uraian tersebut, langkah Polya ini dianggap cocok untuk menganalisis kesulitan siswa dalam mempelajari pecahan karena dimulai dari langkah yang sangat mendasar yaitu memahami masalah sampai dengan langkah yang kompleks yaitu memeriksa kembali kebenaran solusi. Melalui langkah-langkah tersebut, kesulitan mempelajari pecahan akan lebih mudah dianalisis dari yang paling mendasar sampai kompleks. Dengan demikian, tujuan dari penelitian ini adalah untuk menganalisis kesulitan siswa MI dalam mempelajari pecahan berdasarkan langkah Polya dan mendeskripsikan faktor-faktor penyebab kesulitan tersebut.

\section{Metode}

Penelitian ini menggunakan metode deskriptif dengan jenis penelitian kualitatif yang dilaksanakan di salah satu MI Kabupaten Bandung. Subjek penelitian yaitu siswa MI kelas III yang berjumlah 20 orang. Pengambilan subjek tersebut berdasarkan pada 
pengalaman peneliti ketika mengajar sering menjumpai kekeliruan siswa kelas III dalam menyelesaikan soal-soal pecahan. Teknik memperoleh sampel pada penelitian ini menggunakan teknik sampling purposive karena subjek dipilih berdasarkan ciriciri khusus yang ditetapkan peneliti yang sesuai dengan tujuan penelitian. Teknik pengumpulan data yang digunakan adalah tes tertulis tipe uraian dan wawancara. Tes tertulis tipe uraian digunakan untuk mengetahui kesulitan-kesulitan siswa dalam mempelajari pecahan sedangkan wawancara digunakan untuk mengetahui faktorfaktor penyebab kesulitan tersebut. Tes tertulis tipe uraian yang digunakan sebanyak 5 soal terkait pecahan diujicobakan kepada 20 siswa MI kelas III. Kemudian setelah dilaksanakan tes dan diperoleh hasilnya, dipilih 7 orang siswa sebagai sampel untuk wawancara. Pemilihan sampel wawancara tersebut berdasarkan hasil jawaban siswa yang mewakili jawaban mayoritas.

Tes uraian akan dianalisis jawabannya berdasarkan langkah Polya (2004) yaitu, (1) memahami masalah (understanding the problem), siswa harus dapat mengidentifikasi unsur yang diketahui dan ditanyakan serta dapat memeriksa kesesuaian unsur untuk menyelesaikan masalah, (2) menyusun rencana (devising a plan), siswa harus dapat mengaitkan hubungan antara unsur yang diketahui dan ditanyakan kemudian menyusun model/kalimat matematika dengan menyertakan konsep/rumus matematika yang digunakan untuk menyelesaikan masalah, (3) melaksanakan rencana penyelesaian (carrying out the plan), siswa harus dapat menyelesaikan model/kalimat matematika dengan merinci langkah-langkah penyelesaiannya, (4) memeriksa kembali kebenaran solusi (looking back), siswa harus dapat memeriksa kebenaran jawaban dengan cara menurunkan hasil secara berbeda dan menginterpretasikan hasil terhadap masalah awal.

Teknik analisis data pada penelitian ini menggunakan model Miles \& Huberman (1994) yaitu mereduksi data dari jawaban siswa, kemudian menyajikan jawaban siswa berdasarkan langkah Polya dan terakhir dilakukan penarikan kesimpulan sesuai tujuan penelitian.

\section{Hasil dan Pembahasan}

Berdasarkan tujuan dari penelitian ini yaitu untuk menganalisis kesulitan siswa dalam mempelajari pecahan berdasarkan langkah Polya, penelitian ini menganalisis berdasarkan 4 langkah yaitu memahami masalah (understanding the problem), menyusun rencana (devising a plan), melaksanakan rencana penyelesaian (carrying out the plan) dan memeriksa kembali kebenaran solusi (looking back). Adapun data hasil penelitian yang diperoleh dapat dilihat pada Gambar 1 . 


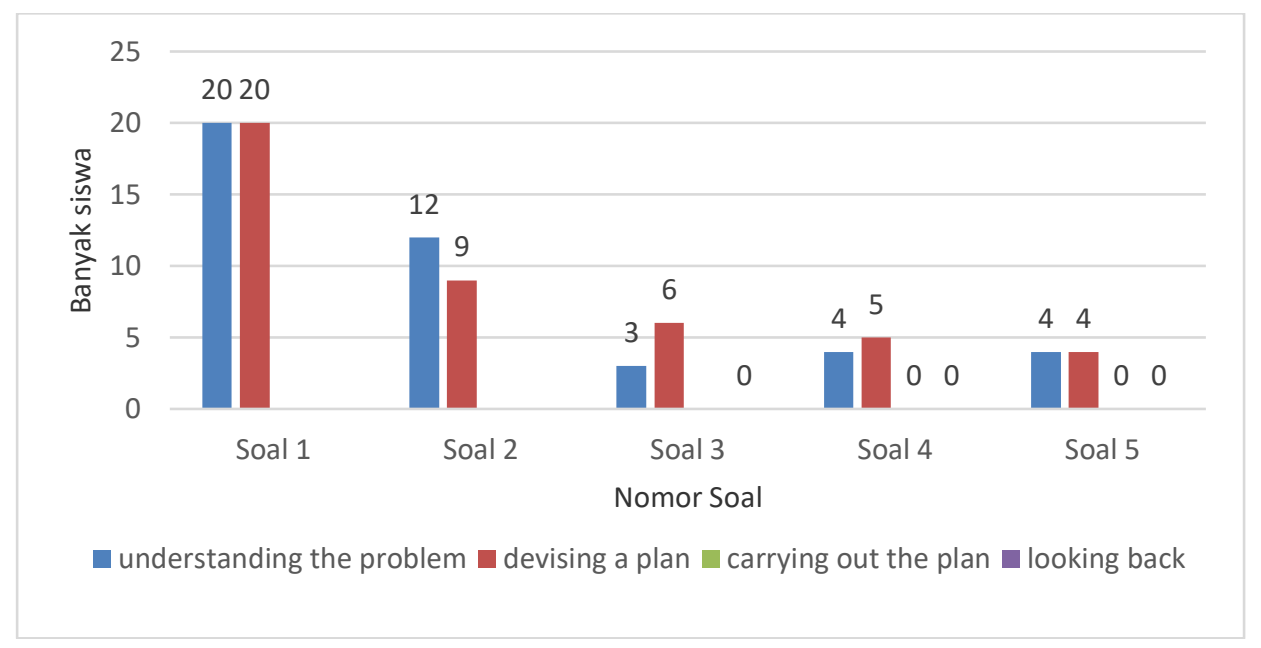

Gambar 1. Hasil Jawaban Siswa dilihat dari Langkah Polya

Gambar 1 menunjukkan bahwa langkah memahami masalah paling tinggi pencapaiannya untuk soal nomor 2 sedangkan pada soal nomor 3 dan 4 langkah menyusun rencana yang paling tinggi dan pada nomor 1 antara memahami masalah dan menyusun rencana penyelesaian pencapaiannya sama. Hal ini terjadi karena untuk soal nomor 1 dan 2 tipe soalnya hanya sebatas memahami masalah sederhana tidak perlu menuliskan unsur yang diketahui dan ditanyakan, cara menjawabnya langsung menuliskan lambang pecahan. Jika dilihat dari hasil jawaban siswa untuk soal nomor 3, 4 dan 5 dengan tipe soal pemecahan masalah dapat kita ketahui siswa lebih banyak mampu menyusun rencana penyelesaian yaitu membuat model matematika dibandingkan menuliskan unsur yang diketahui dan ditanyakan.

Untuk langkah melaksanakan rencana penelitian pada soal nomor 1, 2 dan 3 langkah tersebut belum dimunculkan sedangkan pada soal nomor 4 dan 5 sudah dimunculkan namun tidak ada satupun siswa yang dapat menyelesaikan langkah tersebut dan terakhir langkah memeriksa kebenaran solusi, pada soal nomor 1 dan 2 langkah tersebut belum dimunculkan sedangkan pada soal nomor 3, 4 dan 5 sudah dimunculkan namun tidak ada satupun siswa yang dapat menyelesaikan langkah tersebut.

Hasil tersebut menunjukkan bahwa siswa terbiasa menjawab soal langsung pada jawaban akhir sehingga ketika diminta dalam soal untuk menyertakan proses menjawab soal dari mulai mengidentifikasi unsur yang diketahui sampai memeriksa kembali jawaban siswa merasa kesulitan. Hal ini terlihat dari jawaban siswa yang hanya bisa menjawab dengan menuliskan lambang pecahan saja tanpa menyertakan proses penyelesaiannya. Rendahnya kemampuan siswa dalam menganalisis masalah yang diberikan dan hanya terpaku pada hasil akhir saja merupakan dampak dari pembelajaran matematika yang lebih menekankan kepada keterampilan berhitung 
dengan menggunakan rumus-rumus tercepat daripada penguasaan konsep-konsep (Rostika \& Junita, 2017; Ruchaedi, Suryadi \& Herman, 2015).

\section{Memahami masalah (understanding the problem)}

Memahami masalah dalam matematika yaitu dapat mengidentifikasi dan menuliskan unsur yang diketahui dan ditanyakan serta dapat memeriksa kesesuaian unsur untuk menyelesaikan masalah. Menuliskan unsur yang diketahui dan ditanyakan merupakan hal yang kurang diperhatikan namun sangatlah penting karena untuk dapat menyelesaikan suatu soal matematika berawal dari apa yang diketahui dan ditanyakan dalam soal. Salah satu contoh kesalahan jawaban siswa berdasarkan langkah memahami masalah dapat dilihat pada Gambar 2.

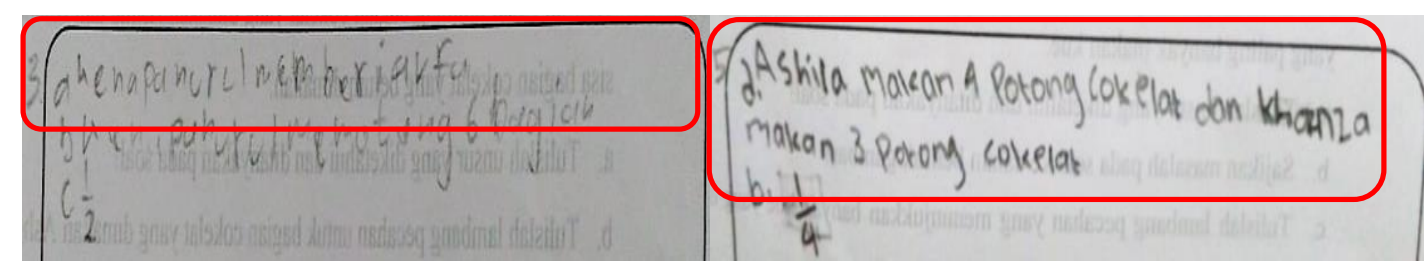

Gambar 2. Kesalahan Jawaban Ditinjau dari Langkah Memahami Masalah

Gambar 2 menunjukkan bahwa masih terdapat kekeliruan dalam menuliskan unsur yang diketahui dan ditanyakan. Pada soal nomor 3 kesalahannya tidak menuliskan unsur yang diketahui, sedangkan unsur yang ditanyakan dituliskan namun tidak sesuai dengan yang ada pada soal. Untuk nomor 5 dapat menuliskan unsur yang diketahui namun hanya sebagian dan tidak dapat menuliskan unsur yang ditanyakan. Padahal unsur diketahui dan ditanyakan merupakan salah satu aspek prasyarat dalam menyelesaikan soal matematika, jika siswa keliru atau tidak bisa menuliskan unsur yang diketahui dan ditanyakan maka berakibat pada kesalahan dilangkah berikutnya (Khasanah \& Sutama, 2015). Berdasarkan paparan tersebut menunjukkan masih adanya kesulitan siswa dalam mengidentifikasi dan menuliskan unsur yang diketahui dan ditanyakan. Hasil tersebut berbeda dengan penelitian sebelumnya yang menyebutkan bahwa kemampuan siswa tergolong rendah dalam melaksanakan rencana penyelesaian dan memeriksa kembali kebenaran solusi (Bernard, Nurmala, Mariam \& Rustyani, 2018). Hal tersebut menunjukkan bahwa kemampuan siswa dalam menuliskan unsur diketahui dan ditanyakan sudah tergolong baik.

Tabel 1. Penggalan Wawancara dengan Siswa 1 (S1)

\begin{tabular}{clc}
\hline Subjek & Isi Percakapan & Baris \\
\hline $\mathrm{P}$ & Untuk no 3a, apa yang S1 pikirkan untuk menjawab pertanyaan tersebut? & 1 \\
S1 & Saya tidak tahu untuk unsur yang diketahui. Tapi, untuk unsur yang & 2 \\
& ditanyakan saya kira diminta untuk membuat pertanyaan. & \\
\hline
\end{tabular}




\begin{tabular}{clc}
\hline Subjek & Isi Percakapan & Baris \\
\hline P & $\begin{array}{l}\text { Apakah sebelumnya pernah menyelesaikan soal cerita dengan terlebih } \\
\text { dahulu menentukan unsur yang diketahui dan ditanyakan? }\end{array}$ & 3 \\
S1 & Tidak pernah, biasanya langsung jawaban akhir saja & 4 \\
\hline
\end{tabular}

Tabel 2. Penggalan Wawancara dengan Siswa 2 (S2)

\begin{tabular}{clc}
\hline Subjek & Isi Percakapan & Baris \\
\hline P & Untuk no 5a, apa yang S2 pikirkan untuk menjawab pertanyaan tersebut? & 1 \\
S2 & $\begin{array}{l}\text { Pertanyaan tersebut memerintahkan untuk menuliskan unsur yang } \\
\text { diketahui dan ditanyakan. }\end{array}$ & 2 \\
P & Apakah jawaban yang S2 tulis sudah sesuai dengan pertanyaan? & 3 \\
S2 & Belum, karena unsur yang diketahui dan ditanyakan belum semua di tulis. & 4 \\
P & Mengapa tidak ditulis semua? & 5 \\
S2 & Karena kepanjangan. Biasanya tidak apa-apa kalau tidak ditulis juga kan & 6 \\
& yang dinilai jawaban akhir saja. & \\
\hline
\end{tabular}

Berdasarkan Tabel 1 dan Tabel 2, hasil wawancara yang dilakukan terhadap 2 orang siswa sebagai sampel diperoleh kesimpulan bahwa siswa terbiasa mengabaikan penulisan unsur yang diketahui dan ditanyakan, yang terpenting adalah mencari jawaban akhir untuk pertanyaan yang diberikan. Selain itu, pendekatan pembelajaran dan bahan ajar yang digunakan di kelas menuntun siswa langsung menyelesaikan soal atau masalah langsung mencari jawaban akhir. Dengan demikian, kesulitan siswa dalam mengidentifikasi unsur yang diketahui dan ditanyakan ini terjadi karena siswa tidak terbiasa dilatih untuk melakukan langkah tersebut. Faktor lain yang mempengaruhi adalah penguasaan konsep prasyarat yang belum matang menyebabkan siswa kesulitan dalam memahami maksud dari soal yang diberikan sehingga kesulitan dalam menuliskan unsur yang diketahui dan ditanyakan yang mengakibatkan kesalahan dalam menentukan unsur-unsur tersebut (Hardiyanti, 2016; Khasanah \& Sutama, 2015; Rahim, 2016; Widyaningrum_ 2016).

\section{Menyusun rencana (devising a plan)}

Menyusun rencana penyelesaian dalam matematika yaitu mengaitkan hubungan antara unsur yang diketahui dan ditanyakan kemudian menyusun model matematika dengan menyertakan konsep/rumus matematika yang digunakan untuk menyelesaikan masalah. Dalam matematika menyusun model matematika itu penting supaya dapat lebih mudah menemukan solusi dari masalah khususnya masalah nyata. Hal ini sejalan dengan Rohaeti, Hendriana \& Sumarmo (2019) yang menyebutkan bahwa model matematika berfungsi sebagai jembatan antara dunia nyata dan dunia abstrak. Salah satu contoh kesalahan jawaban siswa berdasarkan langkah menyusun rencana dapat dilihat pada Gambar 3. 


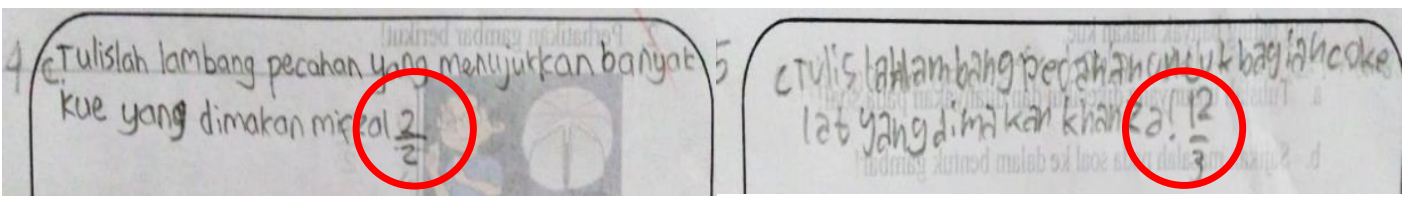

Gambar 3. Kesalahan Jawaban Ditinjau dari Langkah Menyusun Rencana

Gambar 3 menunjukkan bahwa masih terdapat kekeliruan dalam membuat model matematika dalam bentuk lambang pecahan. Pada soal nomor 4 lambang pecahan yang disajikan siswa kurang tepat karena antara pembilang dan penyebut nilainya sama dan itu tidak sesuai dengan yang diketahui dalam soal. Pada soal nomor 5 lambang pecahan yang disajikan siswa terbalik antara nilai pembilang dan penyebut. Berdasarkan paparan tersebut menunjukkan siswa mengalami kesulitan dalam menyusun model matematika yang berkaitan dengan lambang pecahan. Padahal menyajikan lambang pecahan merupakan hal yang sangat penting karena lambang pecahan merupakan inti dari pecahan itu sendiri. Hasil tersebut berbanding terbalik dengan temuan sebelumnya yang menyebutkan bahwa mayoritas siswa sudah bisa menyajikan pecahan ke dalam bentuk gambar dan dari gambar menjadi lambang pecahan (Liestarie \& Karlimah, 2017).

Tabel 3. Penggalan Wawancara dengan Siswa 3 (S3)

\begin{tabular}{lll}
\hline Subjek & Isi Percakapan & Baris \\
\hline P & Untuk no 4c, apa yang S3 pikirkan untuk menjawab pertanyaan tersebut? & 1 \\
S3 & Saya harus menuliskan lambang pecahan untuk kue yang dimakan & 2 \\
& Mifzal. & 3 \\
P & Mengapa S3 menuliskannya seperti ini? & 4 \\
S3 & $\begin{array}{l}\text { Karena kue yang dimakan Mifzal kan 2 potong, terus lambang } \\
\text { pecahankan ada atas dan bawah jadi saya tulis bagian atas dan bawahnya } \\
\end{array}$ & \\
& dengan angka 2 & \\
\hline
\end{tabular}

Tabel 4. Penggalan Wawancara dengan Siswa 4 (S4)

\begin{tabular}{lll}
\hline Subjek & Isi Percakapan & Baris \\
\hline $\mathrm{P}$ & Untuk no 4c, apa yang S4 pikirkan untuk menjawab pertanyaan tersebut? & 1 \\
S4 & Saya harus menuliskan lambang pecahan untuk cokelat yang dimakan & 2 \\
& Khanza. & \\
$\mathrm{P}$ & Mengapa S4 menuliskannya seperti ini? & 3 \\
S4 & Karena cokelat yang dimakan Khanza sebanyak 3 potong dan total & 4 \\
& $\begin{array}{l}\text { cokelat seluruhnya adalah 12 potong. Tapi, saya suka lupa untuk } \\
\text { menentukan nilai pembilang dan penyebutnya suka terbalik. }\end{array}$ \\
\hline
\end{tabular}

Berdasarkan Tabel 3 dan Tabel 4, hasil wawancara yang dilakukan terhadap 2 orang siswa sebagai sampel diperoleh kesimpulan bahwa kesulitan siswa dalam menyajikan model matematika berupa lambang pecahan disebabkan karena siswa masih kurang memahami perbedaan antara pembilang dan penyebut serta kurang 
memahami unsur yang diketahui dan ditanyakan dalam soal. Hal ini sejalan dengan hasil penelitian Deringöl (2019) yang menyatakan bahwa siswa sekolah dasar mengalami kesulitan untuk mempresentasikan pecahan ke dalam bentuk model matematika serta kurang memahami konsep pembilang dan penyebut. Hasil tersebut didukung oleh hasil penelitian Dahlan \& Juandi (2011) yang menyatakan bahwa hanya sebagian kecil siswa menggunakan representasi pernyataan tertulis, simbol dan konjektur serta menggunakan model matematika untuk representasi dalam menjawab soal. Selain itu, pendekatan pembelajaran dan bahan ajar yang digunakan di kelas menuntun siswa langsung memahami bentuk abstrak tanpa diberikan contoh konkrit terlebih dahulu. Seharusnya dalam menyampaikan konsep pecahan harus dimulai melalui kegiatan menggunakan benda konkrit, jika siswa sudah memahami konsep pecahan maka selanjutnya diberikan simbol yang sesuai dengan representasi benda konkrit yang telah mereka lihat dan pahami sehingga pembelajarannya bertingkat dari hal yang konkrit menuju abstrak dan akhirnya dapat menghubungkan dengan hal abstrak dalam kehidupan sehari-hari (Mulyati, 2011; Saleh, Prahmana, Isa \& Murni, 2018). Dilihat dari perkembangan kognitif pun siswa kelas III sekolah dasar masih dalam tahap berpikir konkrit seharusnya penyampaian konsep dimulai dari contoh konkrit terlebih dahulu. Hal ini sesuai dengan teori perkembangan kognitif dari J. Piaget yang mengemukakan bahwa anak 7 - 11 tahun yaitu tingkat sekolah dasar termasuk tahap berpikir operasional konkrit (Ali \& Asrori, 2012).

\section{Melaksanakan rencana penyelesaian (carrying out the plan)}

Melaksanakan rencana penyelesaian yaitu siswa dapat menyelesaikan model/kalimat matematika dengan merinci langkah-langkah penyelesaiannya. Dalam matematika langkah melaksanakan rencana penyelesaian merupakan tujuan yang dianggap paling penting oleh kebanyakan siswa namun melupakan bagaimana langkahlangkah untuk memperoleh penyelesaian akhir tersebut. Salah satu contoh kesalahan jawaban siswa berdasarkan langkah melaksanakan rencana penyelesaian dapat dilihat pada Gambar 4.

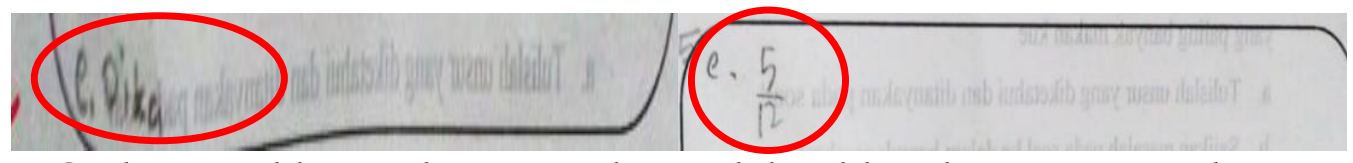

Gambar 4. Kesalahan Jawaban Ditinjau dari Langkah Melaksanakan Rencana Penyelesaian

Gambar 4 menunjukkan bahwa jawaban yang disajikan siswa langsung ke hasil akhir tanpa menuliskan langkah-langkah penyelesaian dan konsep yang digunakan. Seperti pada jawaban nomor 4 menunjukkan bahwa siswa dapat menjawab pertanyaan yang diajukan dengan benar mengenai siapa yang paling banyak makan kue namun tidak menyertakan langkah-langkah berikut konsep yang digunakan untuk memperoleh jawaban tersebut. Padahal jawaban tersebut seharusnya siswa 
menggunakan konsep perbandingan pecahan. Pada jawaban nomor 5 pun sama, siswa dapat menentukan sisa bagian cokelat yang belum dimakan dalam bentuk pecahan dengan benar, namun tidak menyertakan langkah-langkah berikut konsep yang digunakan untuk memperoleh jawaban tersebut. Padahal untuk memperoleh jawaban tersebut seharusnya siswa menggunakan konsep operasi hitung penjumlahan dan pengurangan pecahan. Dengan tidak menyertakan langkah penyelesaian dan konsep yang digunakan namun jawabannya benar, hal ini menimbulkan kesimpulan yang ambigu terkait pemahaman siswa apakah siswa sudah memahami atau hanya menebak-nebak saja. Berdasarkan pemaparan tersebut menunjukkan siswa mengalami kesulitan dalam merinci langkah-langkah penyelesaian masalah yang berkaitan dengan membandingkan pecahan serta operasi hitung penjumlahan dan pengurangan pecahan.

Tabel 5. Penggalan Wawancara dengan Siswa 5 (S5)

\begin{tabular}{lll}
\hline Subjek & Isi Percakapan & Baris \\
\hline P & Untuk no 4e, apa yang S5 pikirkan untuk menjawab pertanyaan tersebut? & 1 \\
S5 & Saya menentukan siapa yang makan kue paling banyak. & 2 \\
P & Mengapa jawaban S5 adalah Dika? & 3 \\
S5 & Iya, karena saya tidak tahu cara menentukannya. Kan disoal ada Mifzal & 4 \\
& dan Dika yang makan kue jadi saya tebak saja Dika. & \\
\hline
\end{tabular}

Tabel 6. Penggalan Wawancara dengan Siswa 6 (S6)

\begin{tabular}{lll}
\hline Subjek & Isi Percakapan & Baris \\
\hline P & Untuk no 5e, apakah betul itu jawaban untuk no 5e? & 1 \\
S6 & Maaf, seharusnya itu jawaban no 5d saya salah tulis. & 2 \\
P & $\begin{array}{l}\text { Oke jika itu untuk 5d. Apa yang S6 pikirkan untuk menjawab } \\
\text { pertanyaan tersebut? }\end{array}$ & 3 \\
S6 & $\begin{array}{l}\text { Saya harus menuliskan sisa bagian coklat yang telah dimakan Ashila } \\
\text { dan Khanza dalam bentuk pecahan }\end{array}$ & 4 \\
& $\begin{array}{l}\text { Apakah dalam soal tidak diminta untuk menuliskan langkah } \\
\text { penyelesaiannya? }\end{array}$ & 5 \\
P & $\begin{array}{l}\text { Pada soal diminta menuliskan langkah penyelesaiannya. Tapi, saya } \\
\text { tidak tahu caranya bagaimana karena biasanya langsung menulis }\end{array}$ & 6 \\
S6 & jawaban akhirnya saja. & \\
& $\begin{array}{l}\text { Lalu bagaimana cara S6 memperoleh jawaban ini? } \\
\text { Kan total cokelat 12 potong, sudah dimakan Ashila 4 potong dan }\end{array}$ & 8 \\
P & $\begin{array}{l}\text { Khanza 3 potong jadi sisanya 5 potong. Di soal diminta untuk ditulis } \\
\text { S6 }\end{array}$ & \\
& $\begin{array}{l}\text { dalam bentuk pecahan jadi lima potong itu ditulis di bagian atas dan bawah adalah banyaknya potongan cokelat keseluruhan. } \\
\end{array}$ & \\
\hline
\end{tabular}

Berdasarkan Tabel 5 dan Tabel 6, hasil wawancara yang dilakukan terhadap 2 orang siswa sebagai sampel diperoleh kesimpulan bahwa kesalahan siswa tidak 
menyertakan langkah-langkah penyelesaian dan konsep yang digunakan karena siswa mengetahui jawabannya namun kesulitan dalam menentukan konsep yang digunakan serta langkah-langkah yang harus dilakukan. Hal ini disebabkan karena siswa kurang memahami unsur yang diketahui dan ditanyakan serta masih kesulitan dalam membuat model matematika. Hal ini sejalan dengan hasil penelitian Bernard, Nurmala, Mariam \& Rustyani (2018) yang menyatakan bahwa terdapat 90\% siswa kurang menguasai langkah penyelesaian masalah sehingga siswa belum bisa mengerjakan proses dan tahap penyelesaian tersebut, hal ini disebabkan siswa tidak memahami keterkaitan dari apa yang diketahui untuk menyelesaikan soal, belum bisa membuat model matematika serta kurang menguasai operasi bilangan. Hasil penelitian lainnya dari Trisniawati (2017) menyatakan bahwa hanya terdapat 23,09\% siswa yang dapat mencapai tahap menyelesaikan masalah. Hal tersebut menunjukkan masih banyak siswa yang mengalami kesulitan dalam langkah melaksanakan rencana penyelesaian.

Faktor lain yang menyebabkan kesulitan siswa dalam langkah melaksanakan rencana penyelesaian adalah pendekatan pembelajaran dan bahan ajar yang digunakan di kelas belum menuntun siswa untuk menyelesaikan masalah/soal dengan merinci langkah-langkah penyelesaian, akan tetapi langsung menjawab hasil akhir saja dengan hanya menyebutkan caranya tanpa dituliskan hal ini dianggap siswa merupakan hal yang abstrak. Padahal kembali lagi kepada tahap perkembangan koginitif siswa yang masih dalam tahap berpikir operasional konkrit belum bisa terlalu memahami lebih jauh mengenai sesuatu yang abstrak.

\section{Memeriksa kembali kebenaran solusi (looking back)}

Memeriksa kembali kebenaran solusi yaitu memeriksa kebenaran jawaban dengan cara menurunkan hasil secara berbeda dan menginterpretasikan hasil terhadap masalah awal. Langkah ini penting dilakukan supaya siswa mengetahui solusi yang diperolehnya benar atau salah. Jika salah maka siswa dapat mengoreksinya dan mengetahui bagian langkah mana yang keliru. Namun, tidak satu pun siswa di kelas tersebut yang menuliskan langkah-langkah untuk memeriksa kembali jawaban yang diperolehnya. Salah satu contoh kesalahan jawaban siswa berdasarkan langkah memeriksa kembali kebenaran solusi yang diperoleh dapat dilihat pada Gambar 5.

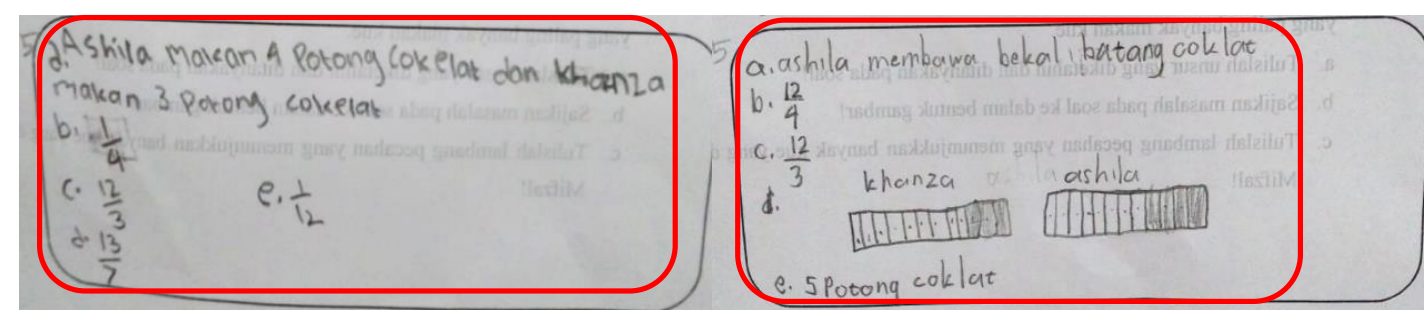

Gambar 5. Kesalahan Jawaban Ditinjau dari Langkah Memeriksa Kembali Kebenaran Solusi 
Gambar 5 menunjukkan bahwa tidak satupun yang mencantumkan langkah memeriksa kembali jawaban yang diperoleh. Pada jawaban nomor 5 sebelah kiri siswa memberikan jawaban akhir (poin e) bukan dalam bentuk lambang pecahan, padahal sudah jelas dalam soal diminta untuk memberikan jawaban dalam bentuk pecahan. Terlihat siswa tersebut tidak memeriksa kembali jawaban yang diperolehnya. Pada jawaban nomor 5 sebelah kanan siswa memberikan jawaban akhir (poin e) dalam bentuk pecahan namun jawaban tersebut salah, jika dilihat dari jawaban sebelumnya yang menuntun ke jawaban akhir tersebut semuanya salah bahkan unsur yang diketahui pun tidak lengkap dan tidak menuliskan unsur yang ditanyakan. Terlihat siswa tersebut tidak memeriksa kembali jawaban yang diperolehnya. Berdasarkan pemaparan tersebut menunjukkan siswa mengalami kesulitan menentukan langkah-langkah untuk memeriksa kembali jawaban yang diperolehnya.

Tabel 7. Penggalan Wawancara dengan Siswa 1 (S1)

\begin{tabular}{lll}
\hline Subjek & Isi Percakapan & Baris \\
\hline P & Sekarang untuk no 5f, apa yang S1 pikirkan untuk menjawab & 1 \\
& pertanyaan tersebut? & \\
S1 & Saya harus mengecek kembali jawaban saya. & 2 \\
P & Apakah sudah dilakukan? & 4 \\
S1 & Sudah & 5 \\
P & Mengapa di sini tidak ditulis langkah saat memeriksa kembali? & 6 \\
S1 & Saya tidak tahu bagaimana menulis langkahnya karena biasanya & \\
& saya tidak diminta untuk mengecek kembali jawaban saya & \\
& menggunakan langkah-langkah. & \\
\hline
\end{tabular}

Tabel 8. Penggalan Wawancara dengan Siswa 7 (S7)

\begin{tabular}{lll}
\hline Subjek & Isi Percakapan & Baris \\
\hline P & Sekarang untuk no 5f, apa yang S7 pikirkan untuk menjawab & 1 \\
& pertanyaan tersebut? & \\
S7 & Saya harus mengecek kembali jawaban saya. & 2 \\
P & Apakah sudah dilakukan? & 4 \\
S7 & Sudah & 5 \\
P & Mengapa di sini tidak ditulis langkah saat memeriksa kembali? & 6 \\
S7 & Saya tidak tahu bagaimana menulis langkahnya karena biasanya & \\
& saya tidak diminta untuk mengecek kembali jawaban saya & \\
& menggunakan langkah-langkah. & \\
\hline
\end{tabular}

Berdasarkan Tabel 7 dan Tabel 8, hasil wawancara yang dilakukan terhadap 2 orang siswa sebagai sampel diperoleh kesimpulan bahwa kesalahan siswa tidak memeriksa kembali kebenaran jawaban yang diperoleh karena siswa tidak mengetahui langkahlangkah untuk memeriksa kembali jawaban tersebut. Setelah siswa menemukan 
jawaban akhir tidak terbiasa untuk memeriksa kembali kebenaran jawaban yang diperoleh. Hal ini disebabkan karena pendekatan pembelajaran dan bahan ajar yang digunakan di kelas belum menuntun siswa untuk memeriksa kembali kebenaran jawaban yang sudah diperoleh. Selain itu, kesulitan pada langkah-langkah sebelumnya juga menjadi salah satu faktor siswa mengalami kesulitan untuk memeriksa kembali kebenaran solusi yang diperolehnya sehingga mengakibatkan besarnya kemungkinan siswa menjawab salah. Siswa yang dapat mencapai tahap melakukan pemeriksaan kembali solusi yang diperoleh masih tergolong rendah hal ini disebabkan siswa tidak memahami keterkaitan dari unsur yang diketahui untuk menyelesaikan soal, belum bisa membuat model matematika serta kurang menguasai operasi bilangan (Bernard, Nurmala, Mariam \& Rustyani, 2018; Trisniawati, 2017).

\section{Simpulan}

Kesulitan siswa dilihat dari 4 langkah Polya sebagai berikut: langkah memahami masalah yaitu siswa tidak dapat mengidentifikasi unsur yang diketahui dan ditanyakan hal ini terjadi karena penguasaan konsep prasyarat yang belum matang serta siswa tidak terbiasa mengidentifikasi masalah dan hanya fokus pada hasil akhir saja; langkah merencanakan penyelesaian yaitu siswa tidak bisa membuat model matematika yang berkaitan dengan lambang pecahan karena siswa kurang memahami konsep pembilang dan penyebut serta kurang memahami unsur yang diketahui dan penyampaian konsep pecahan langsung ke contoh abstrak; langkah melaksanakan rencana penyelesaian yaitu siswa tidak dapat merinci langkah penyelesaian yang harus digunakan hal ini terjadi karena siswa tidak terbiasa menyelesaikan soal dengan merinci langkah penyelesaiannya dan juga siswa kurang memahami unsur yang diketahui dan kesulitan membuat model matematika; langkah memeriksa kembali kebenaran solusi yaitu siswa tidak bisa memeriksa kembali kebenaran jawaban yang telah diperoleh hal ini terjadi karena siswa tidak biasa dituntun untuk memeriksa kembali jawaban yang telah diperolehnya serta pengaruh dari kesulitan yang dihadapi pada langkahlangkah sebelumnya.

Secara keseluruhan pendekatan pembelajaran dan bahan ajar yang digunakan dianggap paling berpengaruh dalam masalah kesulitan siswa mempelajari pecahan ini. Analisis kesulitan ini dapat digunakan oleh guru untuk membuat rencana pembelajaran dengan memperhatikan langkah Polya tersebut.

\section{Daftar Pustaka}

Ali, M., \& Asrori, M. (2012). Psikologi Remaja Perkembangan Peserta Didik. Jakarta: PT Bumi Aksara.

Aminah, \& Kurniawati, K. R. A. (2018). Analisis Kesulitan Siswa dalam Menyelesaikan Soal Cerita Matematika Topik Pecahan Ditinjau dari Gender. JTAM I Jurnal Teori Dan Aplikasi 
Matematika, 2(2), 118-122. https://doi.org/10.31764/jtam.v2i2.713

Bernard, M., Nurmala, N., Mariam, S., \& Rustyani, N. (2018). Analisis Kemampuan Pemecahan Masalah Matematis Siswa SMP Kelas IX pada Materi Bangun Datar. SJME (Supremum Journal of Mathematics Education), 2(2), 77-83. https://doi.org/10.35706/sjme.v2i2.1317

Dahlan, J. A., \& Juandi, D. (2011). Analisis Representasi Matematik Siswa Sekolah Dasar dalam Penyelesaian Masalah Matematika Kontekstual. Jurnal Pengajaran Matematika Dan Ilmu Pengetahuan Alam, 16(1), 128-138. https://doi.org/10.18269/jpmipa.v16i1.273

Deringöl, Y. (2019). Misconceptions of Primary School Students about the Subject of Fractions. International Journal of Evaluation and Research in Education (IJERE), 8(1), 29-38. https://doi.org/10.11591/ijere.v8i1.16290

Hardiyanti, A. (2016). Analisis Kesulitan Siswa Kelas IX SMP dalam Menyelesaikan Soal pada Materi Barisan dan Deret. Prosiding Konferensi Nasional Penelitian Matematika Dan Pembelajarannya (KNPMP I) UMS, 78-88.

Indriani, A. (2016). The Use of Fractional Cards for Fraction Learning in The Fifth Grade Students of Elementary School. JRAMathEdu (Journal of Research and Advances in Mathematics $\quad$ Education), 28-35. https://doi.org/10.23917/jramathedu.v1i1.1783

Kania, N. (2018). Alat Peraga untuk Memahami Konsep Pecahan. Jurnal THEOREMS (The Original Research of Mathematics), 2(2), 1-12. https://doi.org/10.31949/th.v2i2.699

Khasanah, U., \& Sutama. (2015). Kesulitan Menyelesaikan Soal Cerita Matematika pada Siswa SMP. Prosiding Seminar Nasional Pendidikan Matematika UMS 2015, 79-89.

Liestarie, R. R., \& Karlimah. (2017). Analisis Kemampuan Komunikasi Matematis Siswa Kelas III Sekolah Dasar pada Materi Mengenal Konsep Bilangan Pecahan. PEDADIDAKTIKA: Jurnal Ilmiah Pendidikan Guru Sekolah Dasar, 4(1), 109-119.

Miles, M. B., \& Huberman, A. M. (1994). Qualitative Data Analysis, Second Edition. London, UK: SAGE Publications.

Mulyati, T. (2011). Kemampuan Pemecahan Masalah Matematis Siswa Sekolah Dasar. EduHumaniora: Jurnal Pendidikan Dasar, 3(2), 1-15. https://doi.org/10.17509/eh.v3i2

Nasiruudin, F. A. Z., \& Hayati. (2019). Analisis Kesulitan Menyelesaikan Soal Operasi Hitung Pecahan pada Siswa Sekolah Dasar di Makassar. Klasikal: Journal Of Education, Language Teaching And Science, 1(2), 23-31. https://doi.org/10.0906/klasikal.v1i2.31

Peraturan Menteri Pendidikan dan Kebudayaan Republik Indonesia. (2018). Peraturan Menteri Pendidikan dan Kebudayaan Republik Indonesia Nomor 37 Tahun 2018 tentang Kompetensi Inti dan Kompetensi Dasar Pelajaran pada Kurikulum 2013 pada Pendidikan Dasar dan Pendidikan Menengah. Jakarta: Departemen Pendidikan Nasional.

Polya, G. (2004). How to Solve It. A New Aspect of Mathematical Method (With a new foreword by John Conway). New Jersey: Princeton University Press.

Prayitno, A., \& Wulandari, D. T. (2015). Meminimalkan Kesalahan Konsep Pecahan melalui Pembelajaran Penemuan Terbimbing dengan Gesture Produktif pada Siswa SMP. JPM: Jurnal Pendidikan Matematika, I(2), 106-117. https://doi.org/10.33474/jpm.v1i2.718

Rahim, A. (2016). Eksplorasi Kesulitan dalam Menyelesaikan Soal Cerita yang Berkaitan dengan Kelipatan Persekutuan Terkecil dan Faktor Persekutuan Terbesar Ditinjau dari Perbedaan Gender. Prosiding Seminar Nasional Universitas Cokroaminoto Palopo, 02(1), 183190.

Rohaeti, E. E., Hendriana, H., \& Sumarmo, U. (2019). Pembelajaran Inovatif Matematika Bernuansa Pendidikan Nilai dan Karakter. Bandung: Refika Aditama.

Rohmah, S. K. (2019). Analisis Learning Obstacles Siswa pada Materi Pecahan Kelas IV Sekolah Dasar. Al-Aulad: Journal of Islamic Primary Education, 2(1), 13-24. 
https://doi.org/10.15575/al-aulad.v2i1.4428

Rostika, D., \& Junita, H. (2017). Peningkatan Kemampuan Pemecahan Masalah Siswa SD dalam Pembelajaran Matematika Dengan Model Diskursus Multy Representation (DMR). EduHumaniora: Jurnal Pendidikan Dasar, 9(1), 35-46. https://doi.org/10.17509/eh.v9i1.6176

Ruchaedi, D., Suryadi, D., \& Herman, T. (2015). Pengaruh Problem Based Learning (PBL) terhadap Kemampuan Heuristik Pemecahan Masalah dan Sikap Matematis Siswa Sekolah Dasar. EduHumaniora: Jurnal Pendidikan Dasar, 7(1), 72-83. https://doi.org/10.17509/eh.v7i1

Saleh, M., Prahmana, R. C. I., Isa, M., \& Murni. (2018). Improving the Reasoning Ability of Elementary School Student Through the Indonesian Realistic Mathematics Education. Journal on Mathematics Education, 9(1), 41-54. https://doi.org/10.22342/jme.9.1.5049.41-54

Saputri, J. R., \& Mampouw, H. L. (2018). Kemampuan Pemecahan Masalah dalam Menyelesaikan Soal Materi Pecahan oleh siswa SMP Ditinjau dari Tahapan Polya. MATH DIDACTIC: Jurnal Pendidikan Matematika, 4(2), 146-154. https://doi.org/10.1017/CBO9781107415324.004

Suarjana, I. M., Parmiti, D. P., \& Safitri, P. E. A. (2018). Analisis Kesulitan Siswa dalam Menyelesaikan Operasi Hitung Pecahan Siswa Sekolah Dasar. International Journal of Elementary Education, 2(2), 144-155. https://doi.org/10.23887/ijee.v2i2.14417

Trisniawati. (2017). Analisis Kemampuan Pemecahan Masalah Matematis Siswa Tingkat Sekolah Dasar di Kotamadya Yogyakarta. SCIENCE TECH: Jurnal Ilmiah Ilmu Pengetahuan Dan Teknologi, 3(1), 1-10. https://doi.org/10.30738/SCIENCE TECH.V3I1.1135

Widyaningrum, A. Z. (2016). Analisis Kesulitan Siswa dalam Mengerjakan Soal Cerita Matematika Materi Aritmatika Sosial Ditinjau dari Gaya Belajar Siswa Kelas VII SMP Negeri 5 Metro Tahun Pelajaran 2015/2016. Jurnal Iqra': Kajian Ilmu Pendidikan, 1(2), 165190.

Zabeta, M., Hartono, Y., \& Putri, R. I. I. (2015). Desain Pembelajaran Materi Pecahan Menggunakan Pendekatan PMRI di Kelas VII. Beta, 8(1), 86-99. 